\title{
On the stratigraphic Position of the Kathmandu Valley sediments, Nepal
}

Dieser Artikel bildet eine Ergänzung zum Beitrag von Boesch, H.: "Untersuchungen zur Morphogenese im Katmandu Valley", Heft $1 / 74$

Abstract: The stratigraphic position of the Kathmandu valley sediments is discussed and these have been correlated with the Karewa Formation of Kashmir.

Zusammenfassung: Die stratigraphische Stellung der Sedimente des Kathmandu Tals wird diskutiert und mit der Karewa Formation von Kashmir verglichen und korreliert.

The Kathmandu valley constitutes one of the most important areas of the Kingdom of Nepal and occupies an area of $30 \times 25 \mathrm{~km}$. The major part of the valley is covered by plio-pleistocene and recent sediments; its average elevation is 1340 meters. To the north of the valley lies the Sheopuri Lekh $(2689 \mathrm{~m}$.) consisting of precambrian granites, whereas the southern parts are bordered by the Phulchauki Range (3132m.), comprising sediments ranging in age from Precambrian to Devonian. In the eastern and western parts of the valley there are passes of low lying ridges $\left(1800 \mathrm{~m}_{\text {. }}\right)$ near Thankot and Sanga Bhanjyang. The Kathmandu valley is drained by the Bagmati River and its tributaries like Bishnumati, Manohra, Dhobikhola, Hanumante and Nakhukhola. After passing through the centre of the valley, the Bagmati River cuts through a narrow gorge of Chobhar Limestone in the south. The Kathmandu valley is a tectonic valley of the synclinorium type controlled by trough faults in the central part. The geomorphology of the Kathmandu valley has been discussed in detail by YONECHI (1973) and BOESCH (1974) and for detailed maps of the area the reader is referred to these publications.

\section{Kathmandu Valley Sediments}

The Kathmandu valley sediments are of fluviolacustrine nature and consist of clays, sand clays, silts, micaceous sandstones, carbonaceous clays, peat and lignite. These are well exposed near the Tribhawn Air Port, Pashupatnath temple, opposite the Guneshwaridevi temple, Lovenkhel, Lokundol, Harisidhi, Khumbolkhola, Kokdukhola, Guekhola, etc. The thickness of these sediments vary from place to place; near Harisidhi the maximum with about 500 meters has been ascertained.

The lower parts of the Kathmandu valley sedi- ments are intercalated with thick bands of lignite and these are best exposed near Lokundol, Balambu, Phurlong, Gangotikhola, and Lagentole. The hard clay bands overlying the lignite beds near Lokundol (adjoining Chapagaon at the head portion of Nakhukhola) have yielded remains of vertebrate fossils which include Hexaprotodon sivalensis, Arkidiskodon planifrons, Stegodon ganesa, Crocodylus sp. The fauna is identical to the one described from the Upper Karewa Formation of Kashmir and Pinjaur Formation of Siwaliks. The fossils are indicative of a Lower Pleistocene age, but the possibility that they represent in parts a pliocene succession can not be ruled out. The thickness of the lignite seams varies from 1,0 to 1,5 meters; the seams dip towards the centre of the basin.

The upper parts of the Kathmandu valley sediments are essentially sandy and silty with intercalations of carbonaceous and diatomaceous clays. The sediments in the northern part of the valley were derived from the Sheopuri Granite. The sediments of the southern part of the valley comprise pebbly clay conglomerates and diatomaceous earth. The conglomerates are quartzitic in nature and the diatomaceous white clay contains monocotyledonous and dicotyledonous plant fragments. The sediments near Harisidhi consist of several cyc- . les of gravel, powdery sandy soil and clay. The upper part of the succession which has a very wide distribution throughout the valley is also intercalated with bands of peat as well as clay diatomaceous earth, but the thickness of these is much less if compared with the lower part of the succession. The carbonaceous black clays are associated with the diatomaceous white clay and are being used as fertilizer all over the valley. This clay is locally known as "Kalimati" and it is so abundant in the area across Bishnumati in Kathmandu on the Kathmandu-Thankot road that this area is geographically named "Kalimati". The peat and lignite bands in the upper part of the succession contain plant tissues and these vary in thickness from $30 \mathrm{cms}$. to one meter. These are being mined locally for brick burning. At several places in the central part of the valley (at

Dr. V. J. Gupta, Centre of Advanced, Study in Geology, Panjab University, Chandigarh 14, India 
Tanchal, Lahantole, Singh Darbar, Bir Hospital, Patan Industrial District, etc) Inflamable gas is found which is generally associated with the "Kalimati".

Lithologically and palaeontologically the Kathmandu valley sediments can be correlated with the Karewa Formation of Kashmir and both of them seem to have been deposited under similar environments.
Literature

Boesch, $\mathrm{H}_{\text {. }}$ : Untersuchungen zur Morphogenese im Katmandu Valley. GH 1 , S. $15-26,1974$.

Yonechi, F.: A preliminary report on the Geomorphology of Kathmandu valley. Science Report of Yamagata University, 7th Series (Geography), 23(2), S. 153-161,1973.
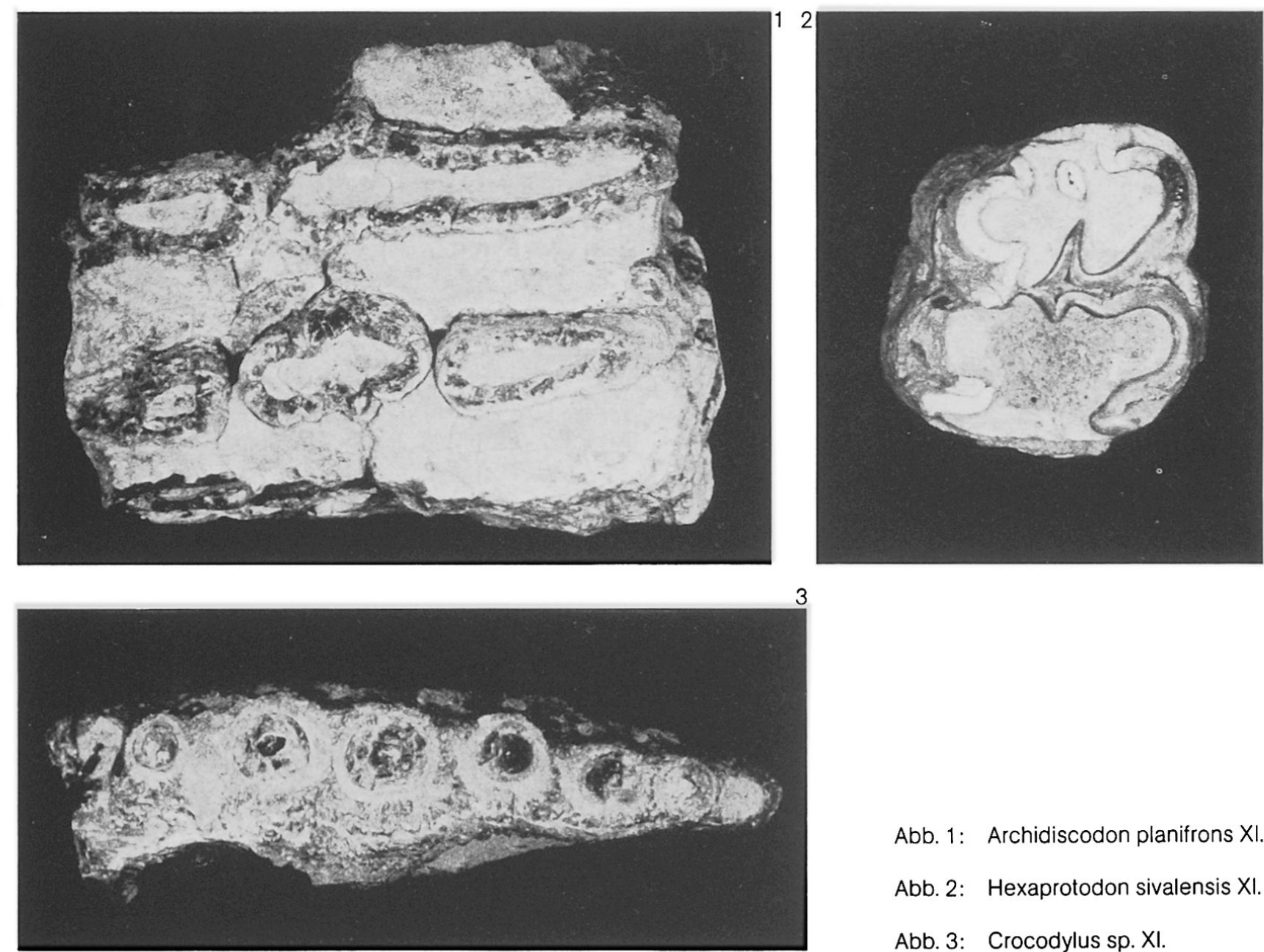

Abb. 1: Archidiscodon planifrons XI.

Abb. 2: Hexaprotodon sivalensis XI.

Abb. 3: Crocodylus sp. XI. 